\title{
The existence of coprophilous macrofungi in Banyumas, Central Java, Indonesia
}

\author{
ARIS MUMPUNI", NURAENI EKOWATI, DANIEL JOKO WAHYONO \\ Faculty of Biology, Universitas Jenderal Soedirman. Jl. Dr. Soeparno 63, Purwokerto, Banyumas 53122, Central Java, Indonesia. \\ Tel. +62-281-638794,Fax: +62-281-631700, ^email: arsmpn@yahoo.com
}

Manuscript received: 3 August 2019. Revision accepted: 27 December 2019.

\begin{abstract}
Mumpuni A, Ekowati N, Wahyono DJ. 2020. The existence of coprophilous macrofungi in Banyumas, Central Java, Indonesia. Biodiversitas 21: 282-289. Coprophilous fungi are cosmopolitan that inhabiting herbivorous animal feces. Some of them are edible mushrooms, as well as hallucinogenic psychotropic fungi that can be used in the pharmaceutical industry. Studies on coprophilous fungi in Indonesia have not been widely carried out. Tropical climate conditions in Indonesia including in the ExResidence of Banyumas, Central Java Province, Indonesia support the growth and spread of coprophilous fungi and are promoted by the spread of herbivorous livestock evenly in almost all regions that always provide suitable dung substrates for the fungal habitat. Based on this background, the purpose of this preliminary study was to obtain coprophilous fungi genera and find out their dominance in the area. This research used survey method with purposive random sampling and focused on macroscopic fungi. The obtained fungi were identified as macro and micro morphologically. From this study, there were 12 genera which were Panaeolus, Coprinopsis, Stropharia, Tricholoma, Lycoperdon, Ascobolus, Rhodocybe, Conocybe, Bolbitius, Leucocoprinus, Mycena, and Hypoloma. The dominance index of the coprophil fungal genera in the ex-residency Banyumas was 0.329; and the coprophil fungi obtained with the highest frequency of occurrence were Coprinopsis (34.4\%) and Panaeolus (30.1\%).
\end{abstract}

Keywords: Herbivorous animal feces fungi, Ex-Residence of Banyumas, dominance index

\section{INTRODUCTION}

Coprophilous fungi are a group of fungi that grow in herbivorous animal dung, which is a complex substrate that contains undigested remnants of vegetation, intestinal animals microbes and various additional components along with their nitrogen content. $\mathrm{pH}$ and humidity of the coprophilous fungi substrate are generally higher than most other substrates that are used by fungi. This group of fungi is ecologically interesting in relation to herbivorous animals that are spread cosmopolite wherever herbivores are, as it is stated by Amandeep et al. (2015) that a number of coprophilous mushrooms in Punjab, India have been observed, growing as saprobes on dung of various domesticated and wild herbivorous animals in pastures, open areas, zoological parks, and on dung heaps along roadsides or along village ponds, etc. This is influenced by the fact that its deployment can be influenced by 3 (three) different ways, namely by the animal itself, by spreading airborne spores and by spores attached to feed ingredients which are often transported to other distant places (Webster 1970). Environmental factors such as temperature fluctuations, photoperiodicity, water potential of the substrate, availability of nutrients in the substrate, the role of other impurities, and competition for interspecific fungal species, will affect species composition in many substrates and their succession (Khiralla 2007).

Coprophilous fungi can act as indicators of habitat diversity (Richardson 2001). In addition, as a waste product from the digestive process, herbivorous impurities are mainly composed of the most resistant and undigested parts of plants which are feed ingredients such as cell wall polymers in the form of cellulose, hemicellulose, and lignin (Krug et al. 2004). Therefore, lytic enzyme of coprophilic fungi that are able to decompose plant cell walls have the potential to be utilized in various types of paper processing, textile, and food processing industries (Ostergaard and Olsen 2010), and hydrolysis of plant biomass into fermentable materials that produce sugar as a biofuel material (Banerjee et al. 2010). Some types of coprophilic fungi are also edible mushrooms that can be developed as protein providers (Mohammed et al. 2017), and some of them are also poisonous mushrooms, especially containing hallucinogenic psychotropic compounds which can be taken as positive ingredients for the production of tranquilizers (Griffiths et al. 2016).

Recognizing the existence of coprophilous fungi from various substrates is beneficial, as stated by Peaky et al. (2010) that identifying and characterizing these cosmopolitan and abundant fungi represents a goal of theoretical and practical significance. The presence of coprophilous fungi in nature, in terms of the type and amount of each type of individual, can show its dominance somewhere. Winfree et al. (2015) confirming that interactions among dominant taxa are predicted to disproportionally affect community stability and functioning; which according to Rivett and Bell (2018) particularly among natural microbial communities. As such, Edigil et al. (2019) also confirmed that determining which fungi are dominant in soils, the environmental variables that drive their abundance and distribution, and common mechanisms underlying dominance capabilities, 
constitute a major scientific advance.

Dominance is a form of control in an area to get food and shelter that is feasible and last long enough. Carter (2019) explained that a dominant species is a plant, animal or functional group of different species most commonly or conspicuously found in a particular ecosystem. It is generally the most populous species or comprises the greatest biomass in an ecosystem. It also influences the distribution of other organisms and helps define the ecosystem and its characteristics. A dominant species might be better at obtaining resources, resisting diseases or deterring competitors or predators than other species.

The study of the coprophilous fungi profile in Indonesia is still not widely carried out, meanwhile tropical climate conditions in most parts of Indonesia. Banyumas District as a part of the ex-residency area reported to have populations of 16.768 both beef and dairy cattle; 1.227 buffaloes; and 227.124 goats, which were spread in 27 Sub-districts (BPS Banyumas 2017). This may figure that the regions always provide livestock manure substrate that is suitable for coprophilous fungal habitat. Based on the above background, it is necessary to conduct an inventory and identification of coprophilous fungi and to know the genus that dominates its existence in the area.

\section{MATERIALS AND METHODS}

\section{Study area}

Sampling location was held in 4 districts in ExResidence of Banyumas, Central Java, Indonesia, ranged between $7^{\circ} 10^{\prime}-7^{\circ} 45^{\prime} \quad S$ and $108^{\circ} 4^{\prime}-109^{\circ} 20^{\prime} \quad$ E, i.e. Banjarnegara, Purbalingga, Banyumas, and Cilacap, respectively (Figure 1), each with 2 chosen sub-districts and every sub-district with 2 villages.

\section{Procedure}

This study was held by elaborating survey method on livestock cages (cattle, buffalo, and goat), from May to October 2018 during which, the weather of the area was relatively hot ranged between $25^{\circ}$ to $32^{\circ} \mathrm{C}$; and $75 \%$ to $90 \%$ humidity. To anticipate, sampling was done early in the morning. Sampling was done twice in each village. Mushrooms in the field were collected according to Lodge et al. (2004), by taking the whole main part of the body by taking it out carefully from its substrate. The mushrooms taken were macroscopic-sized mushrooms that grow in cow, buffalo and goat manures. Every mushroom sample found was photographed using a camera. Samples of coprophilous macrofungi were taken directly from the field, put in plastic boxes and were brought to Laboratory of Mycology, Faculty of Biology Jenderal Soedirman University, Purwokerto, Indonesia as soon as possible after sampling. The samples were then identified using Mycokey 4.1 software (Petersen et al. 2016) by observing both macroscopic characteristics (shape, color, and dimension of pileus, stem, and lamella), and microscopic characteristics (color, form and size of spore deposit) under binocular Boeco Germany BM-180. Either using micrometer and direct object-glass with distilled water.

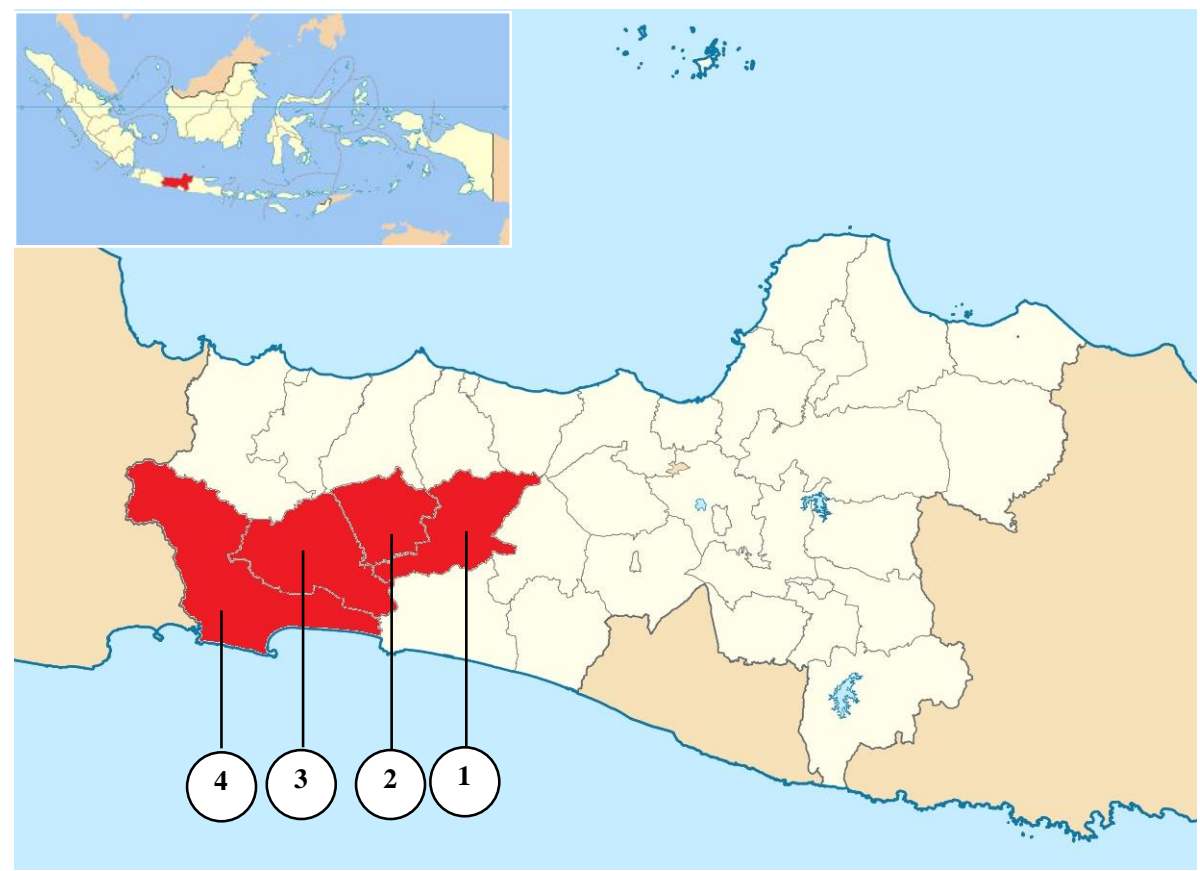

Figure 1. Study site in 4 districts of Banyumas Ex-Residence, southwestern of Central Java Province, Indonesia, include 1. Banjarnegara, 2. Purbalingga, 3. Banyumas, and 4. Cilacap 
The environment parameters were also observed, including $\mathrm{pH}$, temperature, water content, and $\mathrm{C} / \mathrm{N}$ ratio of the substrate. Soil Tester was used to measure $\mathrm{pH}$, and mercury thermometer to measure temperature of the substrate where the fungi collected from. Determination of water content is done by calculating the difference in wet weight and dry weight of the substrate, divided by the wet weight of the substrate, multiplied by $100 \%$ (Rasyid et al. 2010). Determination of organic $C$ substrate was carried out using the Walkey-Black method (Poerwidodo 1992), while total $\mathrm{N}$ was using the Kjeldahl method (Sutedjo 1989). The substrate was the surface of the substrate at the location where the fungus was found.

The dominance of a species shows that the level of adaptation of each type to the environment is different. Dominance index illustrates the pattern of domination of a species to other types in a region (Odum 1971). The notification of fungal samples consisted of location (village, sub-district, district), number of genus found, and number of individuals of each genus then used to count the dominance index using formula as follow (Brower et al. 1990):

$$
\begin{aligned}
& D=\sum \frac{n i[n i-1)}{N(N-1)} \\
& \mathrm{D} \quad \text { : Dominance Index } \\
& \mathrm{ni} \quad \text { : Number of individuals of each genus } \\
& \mathrm{N} \quad \text { : Number of whole individual of all genus } \\
& \text { Criteria: Value of Dominance Index is between } 0-1
\end{aligned}
$$

\section{Data analysis}

Data on fungal morphology, dominance index of coprophilic fungi found, and supporting data $(\mathrm{pH}$, temperature, water content, and $\mathrm{C} / \mathrm{N}$ ratio of the substrate) were analyzed descriptively.

\section{RESULTS AND DISCUSSION}

\section{Results}

Inventory of macroscopic coprophilous fungi in the ExResidence of Banyumas found several fungal genera.

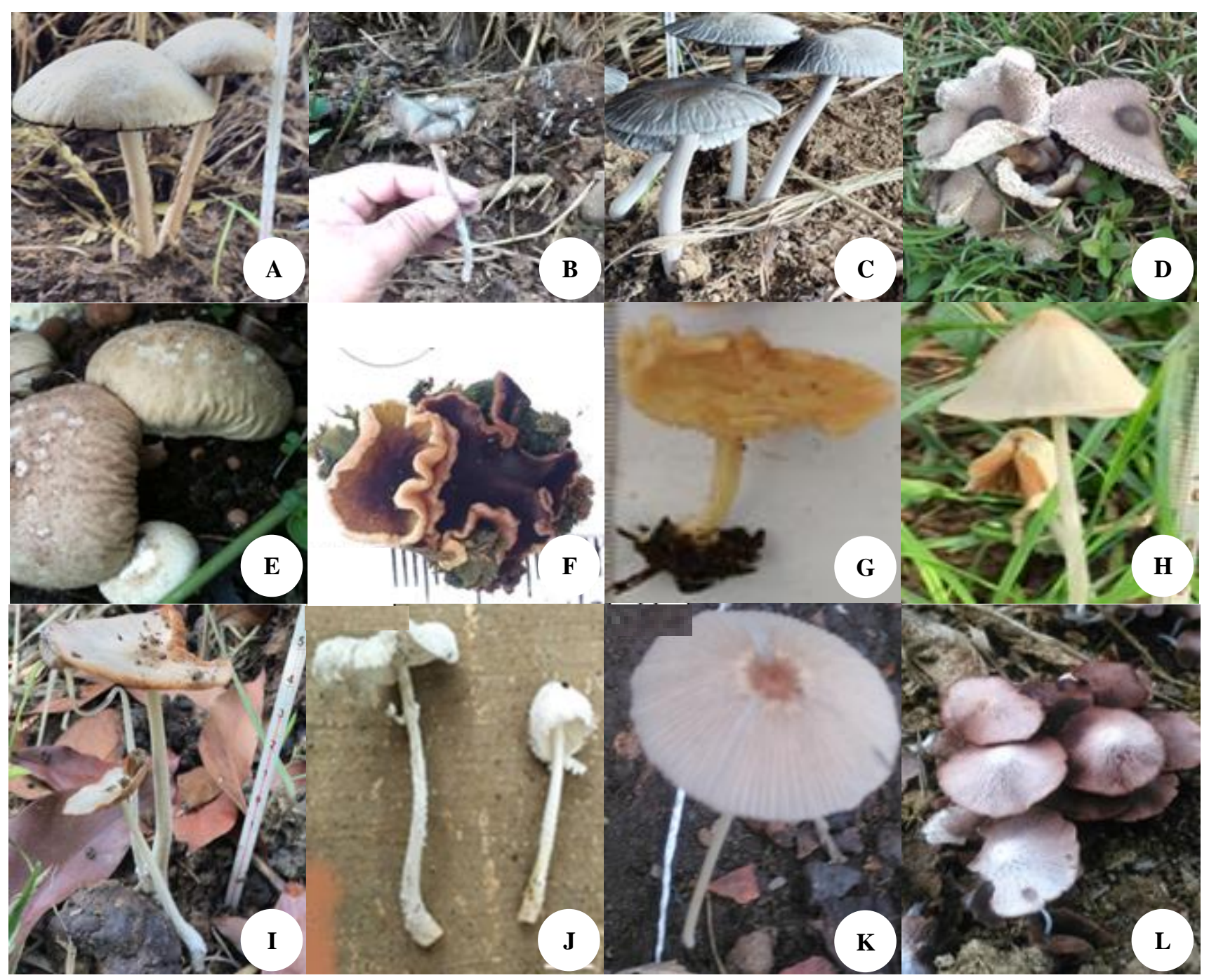

Figure 1. Genera of coprophilous fungi found in Ex-Residence of Banyumas, Central Java, Indonesia. A. Panaeolus, B. Coprinopsis, C. Stropharia, D. Tricholoma, E. Lycoperdon; F. Ascobolus; G. Rhodocybe; H. Conocybe; I. Bolbitius; J. Leucocoprinus; K. Mycena; and L. Hypholoma. 


\section{BIODIVERSITAS}

Volume 21, Number 1, January 2020

Pages: 282-289
ISSN: 1412-033X

E-ISSN: 2085-4722

DOI: $10.13057 /$ biodiv/d210135

Table 1. Coprophilous fungi observed in Ex-Residence of Banyumas, Central Java, Indonesia

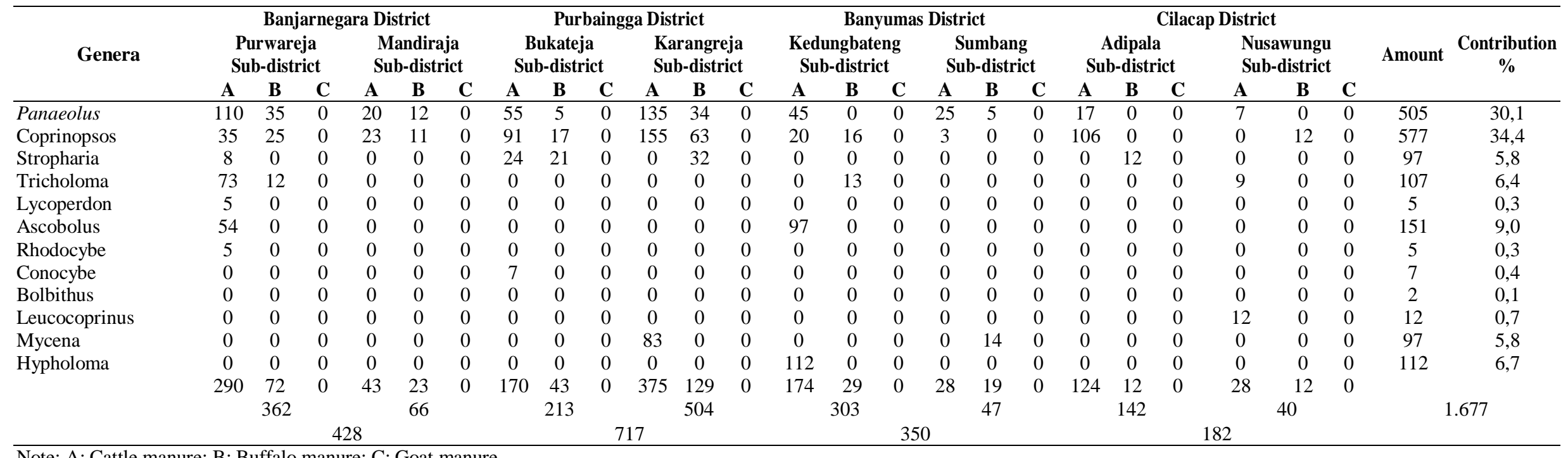

Note: A: Cattle manure; B: Buffalo manure; C: Goat manure 
Table 2. Temperature, $\mathrm{pH}$, water content, $\mathrm{C} / \mathrm{N}$ Ratio and dominance index of coprophilous fungi in the region of Ex-Residence of Banyumas, Central Java, Indonesia

\begin{tabular}{|c|c|c|c|c|c|c|c|c|c|c|}
\hline Region & & $\begin{array}{l}\text { Type of } \\
\text { manure }\end{array}$ & $\begin{array}{l}\text { Tem- } \\
\text { pera- } \\
\text { ture of } \\
\text { subs- } \\
\text { trate } \\
{ }^{\circ} \mathrm{C}\end{array}$ & $\begin{array}{l}\text { Water } \\
\text { content of } \\
\text { substrate } \\
\%\end{array}$ & $\begin{array}{l}\text { pH of } \\
\text { sub- } \\
\text { strate }\end{array}$ & $\begin{array}{l}\text { C/N } \\
\text { Ratio } \\
\text { of sub- } \\
\text { strate }\end{array}$ & $\begin{array}{l}\text { Fungal } \\
\text { Domi- } \\
\text { nance } \\
\text { Index of } \\
\text { manu- } \\
\text { re type } \\
\end{array}$ & $\begin{array}{l}\text { Fungal } \\
\text { Domi- } \\
\text { nance } \\
\text { Index of } \\
\text { Sub- } \\
\text { district } \\
\end{array}$ & $\begin{array}{l}\text { Fungal } \\
\text { Domi- } \\
\text { nance } \\
\text { Index of } \\
\text { District }\end{array}$ & $\begin{array}{l}\text { Fungal } \\
\text { Domi- } \\
\text { nance } \\
\text { Index of } \\
\text { Ex- } \\
\text { Residence } \\
\end{array}$ \\
\hline \multirow{6}{*}{$\begin{array}{l}\text { Banjar- } \\
\text { negara } \\
\text { District }\end{array}$} & Purwa-reja & Cattle & 25 & 73,28 & 6,3 & 16,6 & 0,255 & \multirow[t]{3}{*}{0,210} & \multirow[t]{6}{*}{0,266} & \multirow[t]{24}{*}{0,329} \\
\hline & \multirow[t]{2}{*}{ Sub-district } & Buffalo & 25 & 75,95 & 6,8 & 15,4 & 0,376 & & & \\
\hline & & Goat & 23 & 69,98 & 6,3 & 14,5 & 0 & & & \\
\hline & Mandi-raja & Cattle & 29 & 77,63 & 6,7 & 17,3 & 0,491 & \multirow[t]{3}{*}{0,322} & & \\
\hline & \multirow[t]{2}{*}{ Sub-district } & Buffalo & 28 & 72,88 & 7,4 & 16,4 & 0,478 & & & \\
\hline & & Goat & 25 & 59,03 & 6,2 & 15,0 & 0 & & & \\
\hline \multirow{6}{*}{$\begin{array}{l}\text { Purba- } \\
\text { lingga } \\
\text { District }\end{array}$} & Bukateja & Cattle & 25 & 78,65 & 6,3 & 17,0 & 0,407 & \multirow[t]{3}{*}{0,267} & \multirow[t]{6}{*}{0,252} & \\
\hline & \multirow[t]{2}{*}{ Sub-district } & Buffalo & 25 & 79,58 & 6,5 & 16,7 & 0,394 & & & \\
\hline & & Goat & 23 & 66,28 & 7,0 & 16,0 & 0 & & & \\
\hline & \multirow{3}{*}{$\begin{array}{l}\text { Karang- } \\
\text { reja } \\
\text { Sub-district }\end{array}$} & Cattle & 27 & 76,95 & 6,9 & 16,8 & 0,351 & \multirow[t]{3}{*}{0,238} & & \\
\hline & & Buffalo & 28 & 79,98 & 6,5 & 16,6 & 0,364 & & & \\
\hline & & Goat & 24 & 61,63 & 6,9 & 15,8 & 0 & & & \\
\hline \multirow{6}{*}{$\begin{array}{l}\text { Banyu- } \\
\text { mas } \\
\text { District }\end{array}$} & Kedung- & Cattle & 25 & 77,88 & 6,8 & 17,2 & 0,322 & \multirow[t]{6}{*}{0,109} & \multirow[t]{6}{*}{0,286} & \\
\hline & banteng & Buffalo & 24 & 76,03 & 6,5 & 16,3 & 0,005 & & & \\
\hline & Sub-district & Goat & 21 & 62,65 & 6,4 & 14,7 & 0 & & & \\
\hline & Sumbang & Cattle & 27 & 79,58 & 7,2 & 17,4 & 0,801 & & & \\
\hline & \multirow[t]{2}{*}{ Sub-district } & Buffalo & 25 & 76,28 & 6,8 & 16,5 & 0,590 & & & \\
\hline & & Goat & 25 & 62,95 & 6,2 & 16,0 & 0 & & & \\
\hline & Adipala & Cattle & 29 & 70,98 & 6,9 & 18,3 & 0,759 & \multirow[t]{3}{*}{0,586} & \multirow[t]{6}{*}{0,514} & \\
\hline \multirow{5}{*}{ District } & \multirow[t]{2}{*}{ Sub-district } & Buffalo & 30 & 71,63 & 6,7 & 17,4 & 1 & & & \\
\hline & & Goat & 25 & 67,88 & 6,3 & 15,4 & 0 & & & \\
\hline & \multirow{3}{*}{$\begin{array}{l}\text { Nusa- } \\
\text { wungu Sub- } \\
\text { district }\end{array}$} & Cattle & 28 & 74,03 & 6.7 & 17,8 & 0,325 & \multirow[t]{3}{*}{0,441} & & \\
\hline & & Buffalo & 29 & 72,65 & 6,2 & 16,8 & 1 & & & \\
\hline & & Goat & 27 & 61,58 & 6,0 & 16,1 & 0 & & & \\
\hline
\end{tabular}

Coprinopsis was the most common genus (577 individuals), followed later by the Panaeolus genus (505 individuals), Ascobolus (151 individuals), Hypholoma (112 individuals), Mycena (97 individuals), and several other genera with fewer numbers. Of the 12 genera that can be inventoried, only Ascobolus is a member of the Phylum Ascomycota, while the other 11 genera are members of Phylum Basidiomycota.

Of the three types of substrate, the fungal genera were only obtained from cow and buffalo manure, whereas macrofungi were not found in goat manure in all sampling locations.

By region, the highest number of individual mushrooms was found in Purbalingga District (717 individuals), Banyumas District (484 individuals), Banjarnegara District (429 individuals), and Cilacap District (183 individuals).

\section{Discussion}

Panaeolus, Coprinopsis, Stropharia, Tricholoma, Rhodocybe, Conocybe, Bolbitius, Leucocoprinus, Mycena, and Hypholoma are Basidiomycete fungi with pileus and stipe with agaricoid fruit body type. The fungi found in cattle and buffalo manure. Lycoperdon is also Basidiomycete fungi that do not have pileus and stipe, as this fungus is an epigean gastromycete; Ascobolus found only on cattle manure. The fungus' fruitbody is called apothecia which is formed like a bowl, this is the only Ascomycetes found as macroscopic coprophilous fungi.

The observed environmental factors contributed to the existence and dominance of coprophilous fungi in sampling location, which include temperature and $\mathrm{pH}$ of the substrate, water content and $\mathrm{C} / \mathrm{N}$ ratio of the substrate (Table 2.)

All of the macroscopic coprophilous fungi found grew on cattle and buffalo manures, on mixture of each manure with paddy straw as the exceed of feeding materials, and on soil that has been invested by the manures. However, the fungi were not found on goat manure at all, this is not in accordance with the research of Lestara (2013) who found that coprophilous fungi grew on the manure i.e. Pilobolus, Arthrobotrys, Coprinus, Saccobolus, Oedocephalum, Dactylaria, Kernia, and Cercophora. Coprophilous fungi that can not grow on goat manure may be due to its texture that does not support the macroscopic phase of the fungi, as it was stated by Hartatik and Widowati (2005) that the texture of goat manure are specific forming granules that hard to break physically so this cause to the slow process of decomposition and its nutrient provision.

Growth, composition, and succession of coprophilic fungi are commonly affected by environmental factors such 
as temperature, moisture, $\mathrm{pH}$, water potential, and availability of nutrients in the substrate. The environmental factor data in Table 2. shows the environmental conditions in the form of substrate temperature, substrate water content, substrate $\mathrm{pH}$, and relatively uniform $\mathrm{C} / \mathrm{N}$ substrate ratios between sampling regions. Districts of Banjarnegara, Banyumas, and Purbalingga were similar in their environmental conditions, however, there was a tendency to increase of the substrate temperature and decrease of the substrate water content in the Cilacap District. This is because sampling time which coincides with the dry season. This condition is likely to affect the number of findings of coprophilous fungi in the Cilacap District region which was less than the number of the fungi in the other 3 districts. The fewer number and genera of fungi found in an area tend to support the more dominant fungal genera found.

The $\mathrm{C} / \mathrm{N}$ ratio that ranges from 14.7-18.3 shows relatively high $\mathrm{N}$ content. The $\mathrm{C} / \mathrm{N}$ ratio in that range did not relate to the number of coprophilic fungi obtained and the location and type of feces where the fungi grow. According to Dix (2012), most fungi require high levels of nitrogen. Nitrogen availability is undoubtedly an important factor that can affect the competitiveness of certain fungi. Blakeman (1978) revealed that the natural habitats of fungi, especially of those living in soil, are characteristically determined by a shortage of easily accessible nutrients (simple sugars and amino acids). So, fungi compete for these nutrients. A similar case was also stated by Watanabe et al. (1987) that when nitrogen $(2 \mathrm{~g} / \mathrm{L})$ was added to the liquid growth medium, the weight of the mycelium for the fungi Trichoderma spp. and Gliocladium virens increased, while their surface growth remained unchanged. Most isolates reacted with massive formation of conidia and chlamydospores if the nitrogen concentration was increased. Celar (2003) concluded that a fungus that is capable of quicker and more effective use of various nutrients has a better possibility to survive and to spread in the soil. According to Raymond et al. (2013), although the $\mathrm{C} / \mathrm{N}$ ratio is important, it does not always correlate with growth and biomass of coprophilic fungi, because according to Hutchison and Barron (1996), species of coprophilic fungi may have evolved in adapting to low nitrogen-bearing environments, so nitrogen is not a limiting factor for the growth of the fungus.

The results of the inventory of coprophilic fungi in the Ex-Residence of Banyumas proved that the 12 genera were found in different environments (Table 2.). This could be in accordance with Proborini's statement (2012), that each fungus has a different tolerance to an environmental condition.

The difference in the ability of fungal tolerance to the environment causes certain genera to be able to grow in cow and buffalo manure in all sampling locations. Table 1. shows that the genus Coprinopsis is always found in all locations and even dominates in Cilacap District even though the environmental factors are relatively more extreme than in other regions. This may happen as according to Grainger (1946) Coprinopsis has a wider tolerance for environmental factors such as temperature,
$\mathrm{pH}$ and moisture content of the substrate. Boddy et al. (2007) also stated that Coprinopsis has a fairly combative (aggressive) mycelium growth in a low-nutrient environment, so that Coprinopsis mycelium can grow to dominate. The data in Table 1 . also shows that of the 12 genera obtained, there are 2 genera with the highest frequency of occurrence, namely Coprinopsis (34.4\%) and Panaeolus $(30.1 \%)$, showing that the genera dominate the existence of coprophilous macrofungi in the area.

The second-highest occurrence frequency of Panaeolus in the sampling area may be due to the genus is saprotrophic in habitat and most of the species grow solitary, scattered or in groups on dung and on soil (Pegler 1986). MycoBank (www.mycobank.org) documented 134 associated records of the genus Panaeolus till July 312014 , in addition, Kaur et al. (2014) presented the results of a preliminary study of coprophilous Panaeolus as it occurs in the state of Punjab. An account of 16 Panaeolus species collected from a variety of coprophilous habitats of Punjab state in India i.e. P. alcidis M.M.Moser, P. castaneifolius F.H.Møller, P. papilionaceus var. parvisporus (Bull. ex Fries) Quélet, P. tropicalis Ola'h, P. venezolanus Guzman, $P$. acuminatus (Schaeffer) Quélet, $P$. antillarum (Fr.) Dennis, $P$. ater (J.E. Lange) Kühner \& Romagn, $P$. solidipes (Peck) Sacc., P. sphinctrinus (Fr.) Quél, $P$. subbalteatus (Broome \& Berkeley) Sacc., P. cyanescens (Berk. \& Broome) Sacc., P. africanus Ola'h, P. lepusstercus Atri, P. cyanoannulatus Atri and P. pilocystidiosus Orton.

The genus Panaeolus (Fr.) Quél. is characterized by small to medium-sized carpophores with usually coprophilous habitat; often bluing when bruised or with age; adnexed to adnate, variegated, greyish-black lamellae; epithelial pileus cuticle and reddish-brown to blackish brown spores which do not fade in concentrated sulphuric acid. The gills of Panaeolus do not deliquesce as do those of the related genera Coprinopsis, Coprinellus, and Parasola. The genus Panaeolina Maire is distinguished by having ornamented spores and dark brown gills, in comparison to smooth basidiospores and mottled greyishblack gills in Panaeolus (Kaur et al. 2013).

The role of Ascobolus in decomposition of herbivore dung is important. According to Garrett (1981), as in most other environments, the cellulose in herbivore dung is degraded by a consortium of many different microbes and microfauna, but the fungi are the most apparent and are responsible for the largest proportion of the cellulolysis. True cellulose-decomposing ascomycetes such as Sordaria fimicola and species of Podospora and Ascobolus are often the first species to produce macroscopic fruit bodies on such a substrate generally followed by the appearance of the basidiomycetes, of which members of the genus Coprinus are the most common. It is now clear that the most of these species begin to grow on this substrate very soon after it becomes available, and what was once thought to be a classic succession depends rather more on the time required by many species to produce its fruit bodies than on any sequence of colonization by different organisms. Dovery (2014) found 203 collections (10\%) of Ascobolus 
spp. and 184 collections (9\%) of Saccobolus spp. out of 2092 collections of 214 Ascomycota spp.

Species of Hypholoma are not edible; in fact, those belonging to the group of $H$. fasciculare (Huds.: Fr.) P. Kumm. are considered poisonous (Badalyan et al. 1995). This species has also been investigated for its antioxidant (Badalyan 2003) and hypoglycemic (Badalyan and Serrano 1999) activities. As active wood and litter decomposers, they also play an important role in forest ecosystems, being currently used in bioconversion of cellulose, fabric, and dye industrial residues (Steffen et al. 2000), and also in biological control of phytopathogenic fungi (Chapman et al. 2004).

Genus Mycena produces white spores. Some species of which have a bluish hue, or turns blue at the bottom (Stamets 1996). Mycena is a large genus of small saprotrophic fungi with width size is rarely more than a few centimeters. They are characterized by white spore print, small cone-shaped or bell-shaped hat, with thin brittle stems. Most of them are gray or brown, but some species have bright colors. Most have a translucent hood and striate, rarely with incurved edge. Lamela attached and typically has cystidia. Some species, such as Mycena haematopus author, secrete latex when the stem is damaged, with the smell of bleach.

Mycena is difficult to be identified morphologically to species and some only distinguished by microscopic features such as the shape of cystidia. Some species are edible, while others contain toxins, but the nature of edible is largely unknown, because they are too small to be cooked. There are more than 33 species of Mycena known as bioluminescent, create light known as Foxfire (Desjardin et al. 2008; Desjardin et al. 2010)

The results of sampling and dominance index of coprophilous fungi in the Ex-Residence of Banyumas as can be seen in Table 2. show a D value that is diverse but tends to be no genus that dominates other genera in the community. Based on the calculation, the level of the entire sampling area obtained the dominance index value of 0.329 which indicates there is no dominance of a genus against the others in that location. This value is relatively low, so that it can be said that the mastery of the coprophilous fungi in the sampling location is relatively diffuse, except in the area of Cilacap District which is dominated by Coprinopsis mushroom with a medium dominance category of 0.514 . This is supported by the statement of Krebs (1978), that the interpretation of the level of mastery of types is for $\mathrm{D}=0<\mathrm{D}<0.5$ is low; $\mathrm{D}=0.5<\mathrm{D}<0.75$ is classified as moderate; and $\mathrm{D}=0.75<\mathrm{D}<1$ is high.

\section{ACKNOWLEDGEMENTS}

The author thanks to Rector and Head of Institute of Research and Community Service (LPPM) of Universitas Jenderal Soedirman, Purwokerto, Indonesia for providing permission and funding to run this research through the research scheme of Improvement of Competence 2018.

\section{REFERENCES}

Badalyan SM, Rapior S, Le Quang J, Doko L, Jacob M, Andary C, Serrano JJ. 1995. Investigation of fungal metabolites and acute toxicity studies from fruit-bodies of Hypholoma species (Strophariaceae). Cryptogamie Mycologie 16: 79-84

Badalyan SM, Serrano JJ. 1999. Hypoglycemic activity of poisonous mushroom Hypholoma fasciculare (Fr.) Kumm. Intl J Med Mushrooms 1: 245-250.

Badalyan SM. 2003. Edible and medicinal higher basidiomycete mushrooms as a source of natural antioxidants. Intl $\mathrm{J}$ Med Mushrooms 5: 153-162.

Banerjee G, Scott-Craig JS, Walton JD. 2010. Improving enzymes for biomass conversion: a basic research perspective. Bioenergy Res 3: 82-92.

Beug MW. 2000. Poisonous and hallucinogenic Mushrooms. The Evergreen State College, Olympia, WS.

Blakeman JP. 1978. Microbial competition for nutrients and germination of fungal spores. Ann. Appl. Biol. 89: 151-155.

Boddy L, Frankland J, Van West P. 2007. Ecology of saprotrophic basidiomycetes. Academic Press, Cambridge.

BPS Banyumas. 2017. Banyumas District in Figures 2017. BPS Kabupaten Banyumas, Purwokerto.

Brower J, Jernold Z, Vonende C. 1990. Filed and Laboratory Method for General Ecology. 3rd ed.: W.M.C. Brown Publishers, New York.

Carter KN. 2019. Dominant Species in a Diverse Ecosystem. https://education.seattlepi.com/dominant-species-diverse-ecosystem3936.html

Celar F. 2003. Competition for ammonium and nitrate forms of nitrogen between some phytopathogenic and antagonistic soil fungi. Biol Control 28: 19-24

Chapman B, Xiao G, Myers S. 2004. Early results from field trails using Hypholoma fasciculare to reduce Armillaria ostoyae root disease. Canadian J Bot 82: 962-969.

Desjardin DE, Olivia AG, Stevani CV. 2008. Fungi bioluminescent revisited. Photochem Photobiol Sci 7 (2): 170-182.

Desjardin DE, Perry BA, Lodge DJ, Stevani CV, Nagasawa E. 2010. Luminescent Mycena: new and noteworthy species. Mycologia. 102 (2): 454-477.

Dix NJ, Webster J. 1995. Fungal Ecology. Springer-Science Business Media, B.V., Nederland.

Doveri F.2014. An update on the genera Ascobolus and Saccobolus with keys and descriptions of three coprophilous species, new to Italy. Mycosphere 5 (1): 86-135.

Egidil E, Delgado-Baquerizo M, Plett MJ, Wang J, Eldridge DJ, Bardgett RD, Maestre FT, Singh BK. 2019. Nature Communications https://doi.org/10.1038/s41467-019-10373-z www.nature.com/naturecommunications

Garrett SD. 1981. Soil Fungi and Soil Fertility. $2^{\text {nd }}$ ed. Pergamon Press. Oxford.

Grainger J. 1946. Ecology of the larger fungi. Trans Br Mycol Soc 29 (1): 52-63.

Griffiths RR, Johnson MW, Carducci MA, Umbricht A, Richards WA, Richards BD, Cosimano MP, Klinedinst MA. 2016. Psilocybin produces substantial and sustained decreases in depression and anxiety in patients with life-threatening cancer: A randomized doubleblind trial. J Psychopharmacol 30 (12): 1181-1197.

Hartatik W, Widowati LR. 2005. Pengaruh Kompos Pupuk Organik yang Diperkaya dengan Bahan Mineral dan Pupuk Hayati terhadap Sifatsifat Tanah, Serapan Hara, dan Produksi Sayuran Organik. Laporan Proyek Program Pengembangan Agribisnis. Balai Penelitian Tanah, Kementerian Pertanian, Jakarta. [Indonesian]

Hutchison LJ, GL Barron. 1996. Parasitism of Yeasts by Lignicolous Basidiomycota and Other Fungi. Canadian J Bot 74 (5): 735-742.

Kaur A, Atri NS, Kaur M. 2013. Two new coprophilous varieties of Panaeolus (Psathyrellaceae, Agaricales) from Punjab, India. Mycosphere 4: 616-625

Kaur A, Atri NS, Kaur M. 2014. Diversity of coprophilous species of Panaeolus (Psathyrellaceae, Agaricales) from Punjab, India. Biodiversitas 15: 115-130.

Khiralla AAI. 2007. A Study on the Ecological Group Coprophilous (Dung) Fungi in Khartoum. [Thesis]. University of Khartoum, Sudan. 
Krug JC, Benny GL, Keller HW. 2004. Coprophilous fungi. In: Mueller GM, Bills GF, Foster MS (eds.). Biodiversity of Fungi. Elsevier, Amsterdam.

Lestara IG. 2013. Keanekaragaman Cendawan Koprofil pada Feses Domba Asal Peternakan di Ciampea, Bogor [Thesis]. Institut Pertanian Bogor, Bogor. [Indonesian]

Lodge DL, Ammirati JF, O'Dell TE, Mueller GM. 2004. Collecting and Describing Macrofungi. In: Mueller GM, Bills G, Foster M (eds.) Biodiversity of Fungi Inventory and Monitoring Methods. Elsevier Academic Press. Burlington, USA.

Mohammed N, Shinkafi SA, Enagi MY. 2017. Isolation of Coprophilous Mycoflora from Different Dung Types in Some Local Government Areas of Niger State, Nigeria. Am J Life Sci 5 (3-1): 24-29.

Odum EP. 1971. Fundamentals of Ecology. W.B. Saunders, Philadelphia.

Peay KG, Bidartondo MI, Arnold EA. 2010. Not every fungus is everywhere: scaling to the biogeography of fungal-plant interactions across roots, shoots and ecosystems. New Phytol 185: 878-882

Pegler DN. 1986. Agaric Flora of Sri Lanka. Kew Bull 12: 1-519.

Petersen JH, Gabba A, Laessoe T. Vesterholt J. 2016. The Morphing Mushroom Identifier (MMI). University of Copenhagen, Denmark.

Poerwowidodo. 1992. Metode Selidik Tanah. Usaha Nasional, Jakarta [Indonesian]

Proborini MW. 2012. Eksplorasi dan Identifikasi Jenis-Jenis Jamur Klas Basidiomycetes di Kawasan Bukit Jimbaran Bali. Jurnal Biologi, 16 (2): 45-47. [Indonesian]
Rasyid B, Samosir SS, Sutomo F. 2010. Respon Tanaman Jagung (Zea mays) pada Berbagai Regim Air Tanah dan Pemberian Pupuk Nitrogen. Prosiding Pekan Serealia Nasional, Balai Penelitian Tanaman Serealia, Maros. [Indonesian]

Richardson MJ. 2001. Diversity and occurrence of coprophilous fungi. Mycol Res 105: 387-402.

Rivett DW, Bell T. 2018. Abundance determines the functional role of bacterial phylotypes in complex communities. Nat Microbiol 3: 767772

Stamets P. 1996. Psilocybin Mushroom of the World. Ten Speed Press, Berkeley, USA.

Steffen KT, Hofrichter M, Hatakka A. 2000. Mineralisation of 14Clabelled synthetic lignin and ligninolytic enzyme activities of litterdecomposing basidiomycetous fungi. Appl Microbiol Biotechnol 54: 819-825.

Sutedjo MM. 1989. Analisis Tanah, Air dan Jaringan Tanaman. Rineka Cipta. Jakarta. [Indonesian]

Watanabe N, Lewis JA, Papavizas GC. 1987. Influence of nitrogen fertilizers on growth, spore production and germination, and biological potential of Trichoderma and Gliocladium. J Phytopathol 120: $337-346$

Webster, J. 1970. Presidential address: Coprophilous fungi. Trans $\mathrm{Br}$ Mycol Soc 54: 161-80.

Winfree RW, Fox J, Williams NM, Reilly JR, Cariveau DP. 2015. Abundance of common species, not species richness, drives delivery of a real-world ecosystem service. Ecol Lett 18: 626-635. 